Anais da Academia Brasileira de Ciências (2005) 77(1): 77-94

(Annals of the Brazilian Academy of Sciences)

ISSN 0001-3765

www.scielo.br/aabc

\title{
Mammalian cell invasion and intracellular trafficking by Trypanosoma cruzi infective forms
}

\author{
RENATO A. MORTARA, WALTER K. ANDREOLI, NOEMI N. TANIWAKI \\ ADRIANA B. FERNANDES, CLAUDIO V. DA SILVA, MARIA CECÍlIA D.C. FERNANDES \\ CAROLINA L'ABBATE and SOLANGE DA SILVA
}

Disciplina de Parasitologia, Departamento de Microbiologia, Imunologia e Parasitologia

UNIFESP, Escola Paulista de Medicina, Rua Botucatu, 862, $6^{\circ}$ andar

04023-062 São Paulo, SP, Brasil

Manuscript received on August 31, 2004; accepted for publication on September 22, 2004; presented by Lucia Mendonça Previato

\begin{abstract}
Trypanosoma cruzi, the etiological agent of Chagas' disease, occurs as different strains or isolates that may be grouped in two major phylogenetic lineages: T. cruzi I, associated with the sylvatic cycle and T. cruzi II, linked to the human disease. In the mammalian host the parasite has to invade cells and many studies implicated the flagellated trypomastigotes in this process. Several parasite surface components and some of host cell receptors with which they interact have been identified. Our work focused on how amastigotes, usually found growing in the cytoplasm, can invade mammalian cells with infectivities comparable to that of trypomastigotes. We found differences in cellular responses induced by amastigotes and trypomastigotes regarding cytoskeletal components and actin-rich projections. Extracellularly generated amastigotes of $T$. cruzi I strains may display greater infectivity than metacyclic trypomastigotes towards cultured cell lines as well as target cells that have modified expression of different classes of cellular components. Cultured host cells harboring the bacterium Coxiella burnetii allowed us to gain new insights into the trafficking properties of the different infective forms of $T$. cruzi, disclosing unexpected requirements for the parasite to transit between the parasitophorous vacuole to its final destination in the host cell cytoplasm.
\end{abstract}

Key words: Trypanosoma cruzi, cellular invasion, amastigotes, trypomastigotes, parasitophorous vacuole escape, trafficking, Coxiella burnetii, phylogenetic lineages.

\section{OVERVIEW}

Since the pioneering studies by Herta Meyer and co-workers that initiated in vitro studies of T. cruzi development within cultured cells (Meyer and Xavier de Oliveira 1948) followed by the detailed description provided by James Dvorak and Thomas Hyde on how cells become infected by $T$. cruzi try-

Correspondence to: Renato A. Mortara

E-mail: renato@ecb.epm.br pomastigotes (Dvorak and Hyde 1973), numerous studies have been performed in order to understand the molecular mechanisms that underlie the rather complex process of parasite entry into mammalian host cells. A number of significant contributions have provided evidence for the participation of both parasite and cellular components. Unfortunately, some of this work have established mechanisms that turned out not to be as universal or general as initially supposed (Ming et al. 1995, Ortega-Barria 
and Pereira 1991, Tardieux et al. 1992, 1994). On the contrary, it has become increasingly apparent that a rather complex interplay of signaling cascades involving both parasite and cellular components seems to operate (Burleigh and Woolsey 2002, Yoshida 2002). More recently, the discovery of differences in the invasion mechanisms engaged by metacyclic trypomastigotes from the two major phylogenetic lineages of the parasite opened new possibilities to deepen studies on this already intricate process (Neira et al. 2002).

After entering host cells, trypomastigotes are usually found in an acidic membrane-bound compartment referred to as phagosome or parasitophorous vacuole (PV), from where they eventually escape to differentiate into amastigotes in the cytoplasm (Kress et al. 1975, Ley et al. 1990, Meirelles et al. 1986, 1987, 1992, Milder and Kloetzel 1980, Nogueira and Cohn 1976, Tanowitz et al. 1975). In the course of these studies, it became apparent that amastigotes, prematurely released from infected cells or generated by the extracellular differentiation of released tissue-culture derived trypomastigotes (TCTs), could also infect cultured cells and animals (Behbehani 1973, Hudson et al. 1984, Ley et al. 1988, Nogueira and Cohn 1976). Systematic studies on cell invasion and PV escape carried out in our laboratory have reinforced the notion that each infective form of the parasite displays a unique interplay with the specific target host cell with which it interacts. Not only the parasite infective form is relevant but also the strain (and phylogenetic origin) will determine the outcome of the interaction. Furthermore, if target mammalian cells are doubly infected with Coxiella burnetii, the destination and nature of the intracellular compartments that contain $T$. cruzi infective forms will also be affected. The variety of mechanisms used for invasion and escape from the parasitophorous vacuoles engaged by amastigotes and trypomastigotes is consistent with the complex repertoires of both infective forms and surface molecules that the parasite has evolved to ensure host colonization.

\section{EARLY OBSERVATIONS ON THE ENTRY OF TRYPOMASTIGOTES AND EXTRACELLULAR AMASTIGOTES IN HeLa AND Vero CELLS}

It has become increasingly evident that several intracellular pathogens specialized in subverting host cell pathways to their benefit. This is particularly well characterized for invasive bacteria such as Shigella, Listeria and enteropathogenic Escherichia coli (EPEC) (Bourdet-Sicard et al. 2000, Cossart 1997, Dramsi and Cossart 1998, Frischknecht and Way 2001, Goosney et al. 2000). Interaction between EPEC and HeLa cells involved aggregation of surface microvilli at the points where the bacterium attached to the dorsal surface of cultured HeLa cells (Silva et al. 1989). In order to promote the interaction, the bacteria were centrifuged onto the cells and actin aggregation was monitored by staining cells with fluorescently labeled phalloidin, using what is now known as the FAS (fluorescent actin staining) assay (Silva et al. 1989). Earlier data in the literature indicated that amastigotes (or amastigote-like forms) could be generated by the extracellular differentiation of trypomastigotes and these forms were capable of invading cultured cells (Behbehani 1973, Hudson et al. 1984, Ley et al. 1988, Nogueira and Cohn 1976). Using the EPECderived protocol, we then centrifuged extracellular amastigotes of the G strain onto HeLa cells and observed that they promptly aggregate actin filaments by attaching to dorsal surface microvilli (Mortara 1991). Microvillus aggregation was followed by the formation of cup-like structures underneath the parasite (Figure 1), that resemble the pedestals formed during EPEC attachment/effacing (Rosenshine and Finlay 1993). Extracellular amastigote invasion can be easily detected by several techniques, including freeze-fracture replicas of recently-infected HeLa cells (Figure 2).

By contrast, trypomastigotes enter HeLa cells by penetrating at their borders (Mortara 1991), a behavior that had been described by Schenkman et al. (1988). Interestingly, the invasion of HeLa cells by trypomastigotes induced the formation of previously undescribed actin-rich pseudopodial protru- 


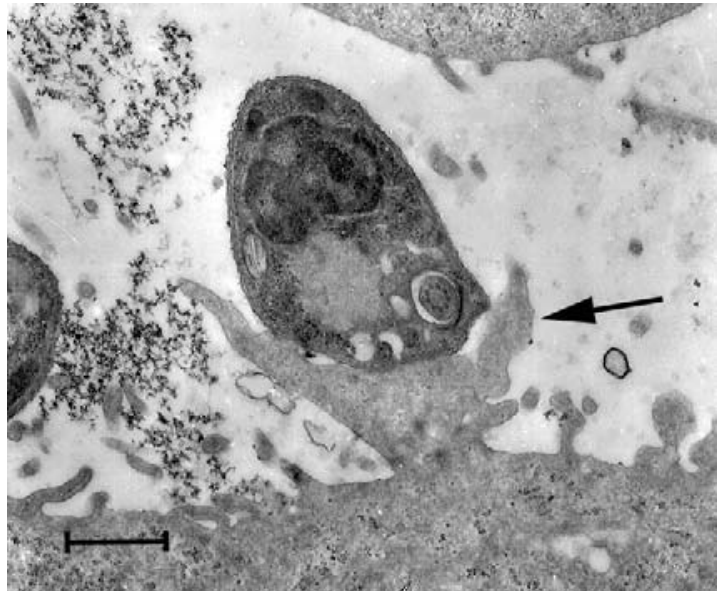

Fig. 1 - Formation of a cup-like pedestal (arrow) upon invasion of HeLa cells by extracellular amastigotes. Transmission electron microscopy of HeLa cells recently infected with G strain extracellular amastigotes. Bar: $500 \mu \mathrm{m}$.

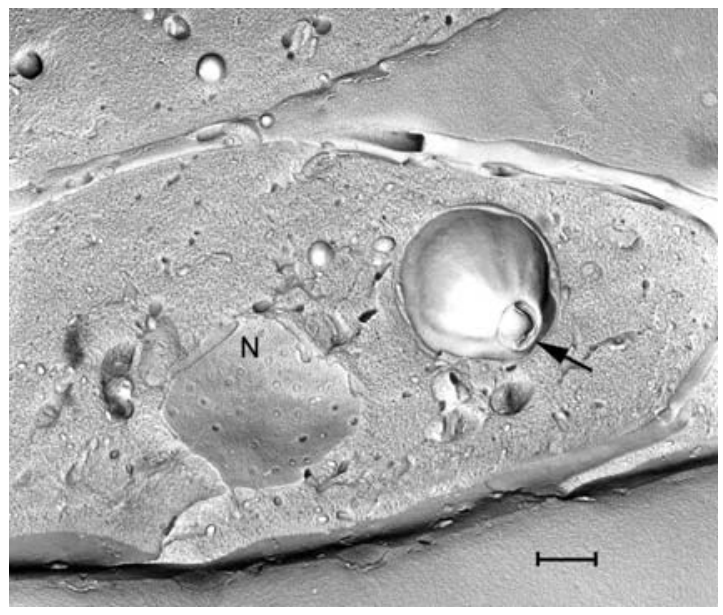

Fig. 2 - Extracellular amastigotes are highly infective to HeLa cells and are promptly visualized in the cytoplasm. Freezefracture replica of recently invaded parasite inside a HeLa cell. The parasite flagellar pocket (arrow) can be clearly seen and the nuclear membrane of the host cell $(\mathrm{N})$ identified by the presence of nuclear pores. Bar: $400 \mu \mathrm{m}$.

sions around the parasites (Figure 3, Schenkman and Mortara 1992). This phenomenon was not inhibited by cytochalasin D indicting that the major driving force derived from the parasite, and was detected in HeLa but not in MDCK cells (Schenkman

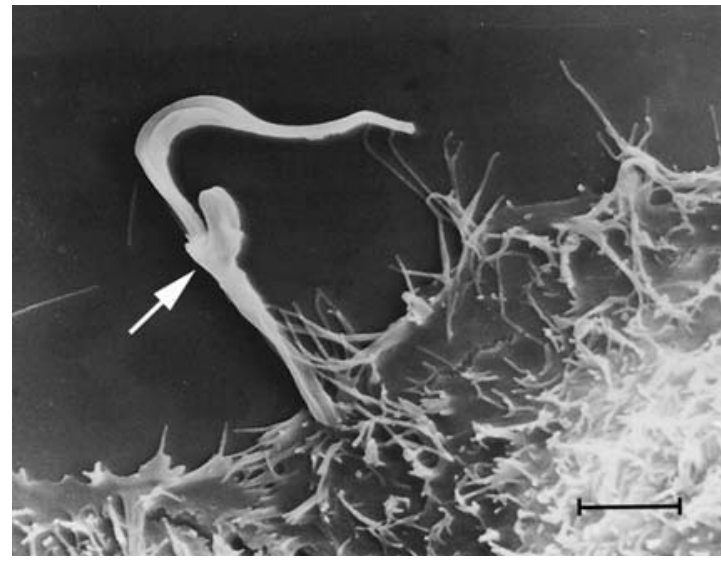

Fig. 3 - Formation of sleeve-like pseudopodia around trypomastigotes invading HeLa cells. Scanning electron microscopy showing the membrane expansion (arrow) around the invading trypomastigote (Schenkman and Mortara 1992). Bar: $2 \mu \mathrm{m}$.

and Mortara 1992). Later on, other investigators found similar pseudopodial extensions around trypomastigotes invading cadiomyocytes (Barbosa and Meirelles 1995).

We further investigated the entry of extracellular amastigotes into HeLa and Vero cells using the centrifugation protocol and compared the results with metacyclic trypomastigotes. First, we confirmed that the mechanisms of cell invasion used by the two forms is distinct, in line with results of Schenkman et al. (1991a) that observed no competition towards cell binding between the two forms. We then treated the mammalian target cells with cytochalasin D and nocodazole to evaluate the role of actin and tubulin mobilization. Cytochalasin D always inhibited amastigote invasion indicating that unlike what was observed for trypomastigotes, amastigotes had a more passive role in the entry process. Nevertheless, the main conclusion was that the effect of a particular drug was specific and unpredictable (inhibitory or stimulatory) for a parasite infective form and a particular host cell (Procópio et al. 1998).

Besides the formation of the surface cups in HeLa cells, we also noticed a remarkable response to extracellular amastigotes when they invade Vero 
cells. In this fibroblastic cell line devoid of surface microvilli, protrusive lamellae formed at the sites of amastigote invasion (Procópio et al. 1999) were markedly similar to shown by attaching Shigella flexneri (Bourdet-Sicard et al. 2000, Clerc and Sansonetti 1987, Tran et al. 2000). In figure 4 the co-localization of different actin-binding proteins and actin filaments in the membrane projections involved in T. cruzi invasion of HeLa and Vero cells is illustrated. In all the actin-rich membrane extensions formed around invading amastigotes or trypomastigotes, accumulation of cytoskeletal elements, integrins or matrix elements could be detected, with some variability observed between the infective forms and target cells (Procópio et al. 1999). These results were again consistent with the notion that each parasite-host cell pair mobilizes specific interacting components (see Table I).

\section{INTRACELLULAR VS. EXTRACELLULAR AMASTIGOTES AS INFECTIVE FORMS OF THE PARASITE}

Although intracellular amastigotes are larger and slightly more elongated than extracellular forms (Barros et al. 1996), they share biochemical and ultrastructural similarities (Andrews et al. 1987, Ley et al. 1988, Villalta and Kierszenbaum 1982) and express similar antigenic stage-specific markers (Andrews et al. 1987, Barros et al. 1997, Pan and McMahon-Pratt 1989, Silva et al. 1998, Verbisck et al. 1998). Studies with strains of T. cruzi I and II, suggest that the expression of the epitopes defined by monoclonal antibodies may vary considerably among intracellular and extracellular amastigotes of the two lineages (Verbisck et al. 1998). Further studies with isolates from chagasic patients tend to confirm this extensive polymorphism (Silva C.V., unpublished observations).

While previous results from the literature have provided conflicting evidence regarding the infectivity of T. cruzi intracellular amastigotes (Carvalho et al. 1981, Ley et al. 1988, Ulisses de Carvalho and De Souza 1986, Umezawa et al. 1985), there are reports that infective extracellular amastigotes resist antibody-independent complement lysis (Iida et al. 1989). We found that intracellular amastigotes (isolated from infected cells) of strains from both $T$. cruzi I or $T$. cruzi II groups are highly susceptible to complement lysis and poorly infective to either Vero or HeLa cells, as well as to MDCK cells transfected with Rho GTPases (Barros 1996, Fernandes and Mortara 2004). A plausible explanation for these results is that intracellular amastigotes are committed to growth within a sheltered environment whereas extracellular forms have to cope with a more hostile milieu where they may encounter not only specific antibodies (Andrews 1989) but also complement proteins (Iida et al. 1989). Acquisition of complement resistance and infectivity by extracellular amastigotes is certainly an interesting and as yet poorly understood process that deserves further investigation.

\section{T. cruzi INVASION OF CELLS TRANSFECTED WITH CYTOSKELETAL ELEMENTS, CARBOHYDRATES OR REGULATORY Rho-GTPases}

In the course of our studies we used a number of available cell lines with altered expression of distinct components. Cytoskeletal mutants of a melanoma cell line expressing varying amounts of actin binding protein 280, ABP280 (Cunningham et al. 1992), a microfilament cross-linking protein, as well as NIH mouse fibroblasts expressing variable amounts of the actin assembly regulator protein gelsolin (Cunningham et al. 1991) display distinct susceptibility towards metacyclic trypomastigotes or extracellular amastigotes of the $\mathrm{G}$ strain (Procópio et al. 1998). We also observed that $\mathrm{CHO}$ cells with poorly sialylated proteins (Lec-2 cells, Deutscher et al. 1984) are slightly more susceptible to extracellular amastigotes, when compared to the normal controls (Stecconi-Silva et al. 2003).

The observation that amastigotes and trypomastigotes become associated with distinct actinrich projections upon cell invasion prompted us to examine the role of regulatory Rho GTPases in this process. Constitutively activated (GTPase activity deficient) mutants of RhoA and Rac1 were found to 

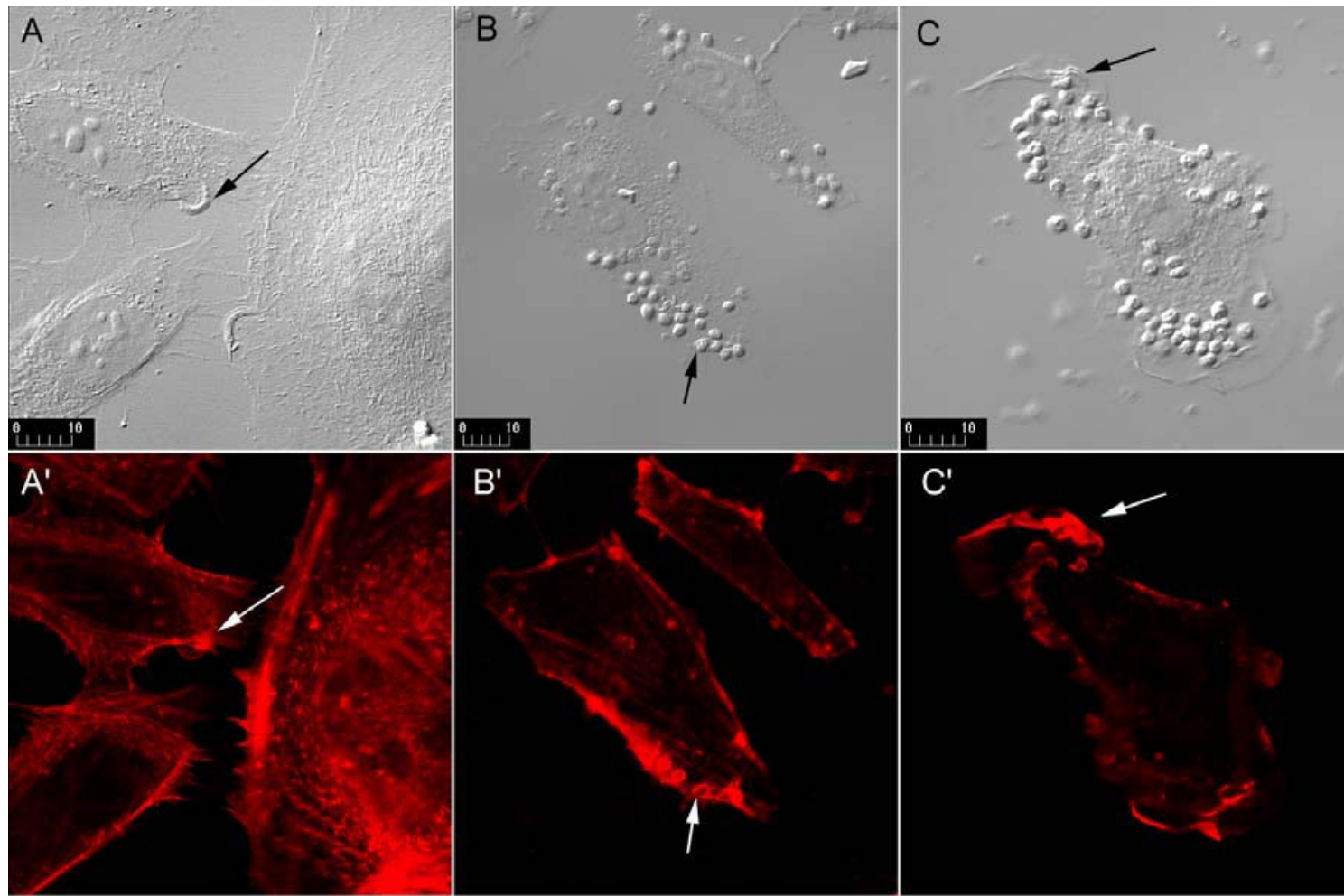

$\mathrm{B}^{\prime}$
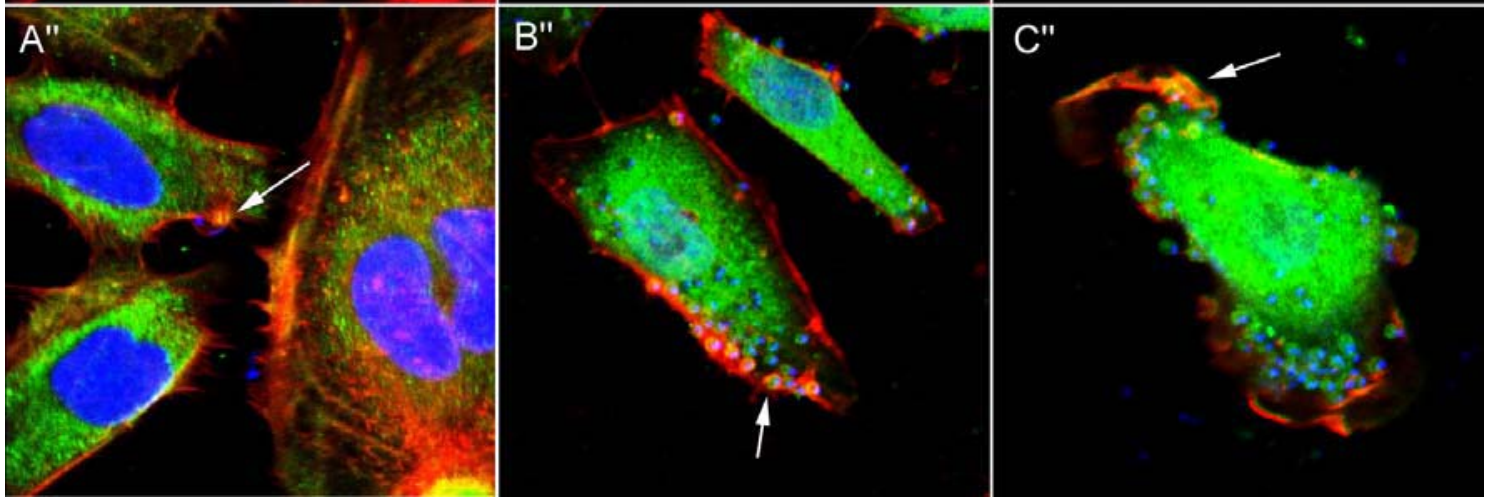

Fig. 4 - Formation of actin-rich membrane extensions around invading T. cruzi infective forms (arrows). A: formation of sleeve-like pseudopodia around trypomastigotes invading HeLa cells, Nomarski DIC image; A': f-actin labeling with phalloidin-Rhodamine; A": merged image of actin (red), cytoplasmic f-actin binding protein ABP280 (green), and DNA labeling with DAPI (blue). B: formation of cup-like projections around amastigotes invading HeLa cells, DIC image; B': f-actin labeling with phalloidin-Rhodamine; B": merged image with actin (red), cytoplasmic f-actin binding protein gelsolin (green), and DNA labeling with DAPI (blue). C: Crater-like projections around amastigotes invading Vero cells, DIC image; C': f-actin labeling with phalloidin-Rhodamine; C": merged image of actin (red), cytoplasmic f-actin binding protein tropomyosin (green), and DNA labeling with DAPI (blue) (Procópio et al. 1999). Magnification bars in $\mu \mathrm{m}$. 
TABLE I

Invasion of cultured cells by $T$. cruzi I and II infective forms.

\begin{tabular}{|c|c|c|c|c|}
\hline & \multicolumn{2}{|c|}{ T. cruzi I } & \multicolumn{2}{|c|}{ T. cruzi $\mathrm{II}^{1}$} \\
\hline & Meta $^{2}$ & $\mathrm{Ama}^{2}$ & Meta & Ama \\
\hline Actin-rich projection in HeLa cells & pseudopodium & cup & pseudopodium & cup \\
\hline Actin-rich projection in Vero cells & none & crater & none & ND \\
\hline Infectivity towards HeLa and Vero cells & low & high & high & low \\
\hline Infectivity to MDCK Rho-Transfectants & low & high & high & low \\
\hline $\begin{array}{l}\text { Cell invasion requires } \mathrm{Ca}^{2+} \text { mobilized } \\
\text { from acidocalcisomes }{ }^{2}\end{array}$ & yes & yes & no & yes \\
\hline $\begin{array}{l}\text { Cell invasion requires } \mathrm{Ca}^{2+} \text { mobilized } \\
\text { from IP-dependent compartments }{ }^{2}\end{array}$ & no & no & yes & no \\
\hline $\begin{array}{l}\text { Effect of } C \text {. burnetii on parasite invasion } \\
\text { of Vero cells }\end{array}$ & Decrease & Increase & Decrease & Increase $^{3}$ \\
\hline $\begin{array}{l}\text { Effect of weak bases and vacuolar } \mathrm{H}^{+} \\
\text {pump inhibitors }{ }^{4} \text { on invasion of Vero } \\
\text { cell colonized with } C \text {. burnetii }\end{array}$ & Decrease & Increase & Increase & Increase \\
\hline
\end{tabular}

induce the assembly of contractile actin and myosin filaments (stress fibers) and actin rich surface protrusions (lamellipodia), respectively (Hall 1994, Ridley et al. 1992, Ridley and Hall 1992). Later, Cdc42 was shown to promote the formation of actinrich, finger like membrane extensions (filopodia) (Kozma et al. 1995, Nobes and Hall 1995). Thus, RhoA, Rac1, and Cdc42 regulate three separate signal transduction pathways, linking plasma membrane receptors to the assembly of distinct filamentous actin structures. In order to evaluate the relative importance of RhoA GTPases in host cell invasion by different $T$. cruzi infective forms of distinct strains, we used MDCK cells transfectants that express variants of RhoA, Rac1 and Cdc42 proteins (Jou and Nelson 1998). We demonstrated that metacyclic trypomastigotes from strains of $T$. cruzi I presented lower infectivity than $T$. cruzi II parasites for the different target cells, with no apparent specific requirement for GTPases (Fernandes and Mortara 2004). As previously noted, regardless of the strain analyzed, intracellular amastigotes were not only susceptible to complement lysis but also showed very low infectivity towards the different transfectants. Extracellular amastigotes from $\mathrm{G}$ strain infected transfected MDCK cells more efficiently than the other strains. Invasion was particularly high in Rac1V12 cells and was specifically reduced in the corresponding dominant negative line Rac1N17 suggesting a key role for Rac in this invasion process (Fernandes and Mortara 2004).

\section{CELL INVASION BY EXTRACELLULAR AMASTIGOTES AND METACYCLIC TRYPOMASTIGOTES OF STRAINS FROM THE TWO MAJOR PHYLOGENETIC LINEAGES}

Several laboratories have confirmed the observation that $T$. cruzi infective forms from different strains display distinct infectivities towards cells and animals (Alves et al. 1986, Meirelles et al. 1982b, Melo and Brener 1978). Recent characterization of two major phylogenetic lineages of the parasite established that T. cruzi I strains are associated with the sylvatic cycle whereas $T$. cruzi II isolates 
are found mainly in patients and vectors in human dwellings (Souto et al. 1996). The comprehensive work by Nobuko Yoshida and co-workers (see below) established that metacyclic trypomastigotes from $T$. cruzi I (G strain) engage different signaling mechanisms to invade HeLa cells when compared to T. cruzi II (CL strain) (Neira et al. 2002).

When we initiated the studies of extracellular amastigote infection, it soon became apparent that these forms of the $\mathrm{G}$ strain (T. cruzi I) were usually much more infective than the corresponding metacyclic trypomastigotes. This was true not only for Vero and HeLa cells (Mortara 1991, Procópio et al. 1998, Procópio et al. 1999) but also for the sialic acid mutant Lec-2 cells (Stecconi-Silva et al. 2003). Of all target mammalian cells employed so far, only in the case of MDCK cells and the Rho transfectants, was metacyclic trypomastigotes infectivity higher than the corresponding extracellular amastigotes (see Table I and Fernandes and Mortara 2004).

When the infectivity of extracellular amastigotes derived from sylvatic type I strains was systematically compared to type II parasites, we always found that the former, particularly of the $G$ strain, were much more infective (Barros 1996, Fernandes and Mortara 2004, Mortara et al. 1999). Interestingly, this higher infectivity trend followed the expression of a surface carbohydrate epitope defined by Mab 1D9 (Barros et al. 1997), that is correspondingly high in extracellular amastigotes of $T$. cruzi I strains and low in T. cruzi II isolates (Mortara et al. 1999, Verbisck et al. 1998). Moreover, the carbohydrate epitope defined by Mab 1D9 is present in the same protein that also contains another epitope designated Ssp-4, defined by Mab 2C2 (Andrews et al. 1987, Barros et al. 1997). Unlike 2C2 that is restricted to the surface of intracellular and extracellular amastigotes, the epitope defined by Mab 1D9 is also present in intracellular compartments such as cytoplasmic vesicles and Golgi apparatus (Barros et al. 1997). Consistent with the higher expression on the more infective T. cruzi I extracellular amastigotes, Mab 1D9 and its Fab fragments were also shown to specifically inhibit parasite invasion (Barros et al. 1993, Barros 1996). Unfortunately, due to the nature of the immunoglobulin (IgG3) that precipitated upon isolation, the identification of this epitope of extracellular amastigotes has so far not been possible.

Why extracellular amastigotes of highly infective strains such as Y and CL are poorly infective when compared to type I parasites, particularly $\mathrm{G}$ forms, showing the opposite behavior of the related trypomastigotes? This is a trend that we constantly found and that, so far we don't have a reasonable explanation. One highly speculative possibility is that subpatent infection caused by type I parasites (such as that found in experimental mice) could be at least in part sustained by the generation of infective extracellular amastigotes. Scharfstein and Morrot (1999) proposed that extracellular amastigotes (of either T. cruzi type) could also play a role by aggravating the pathology in the chronic phase of the disease. Possible differences in the expression of surface ligands required for cell invasion should also being considered (see below).

Signalling Mechanisms: Role of Calcium Ions FROM ACIDOCALCISOMES OR $\mathrm{IP}_{3}$-DEPENDENT COMPARTMENTS

As indicated above, metacyclic trypomastigotes of the two major phylogenetic lineages use highly divergent signaling mechanisms to invade host cells. Using drugs to inhibit specific pathways, Yoshida and collaborators demonstrated that $T$. cruzi I trypomastigotes (the prototype being $G$ strain) engage adenylate cyclase activation for cellular invasion whereas CL strain parasites (T. cruzi II prototype) depend on tyrosine phosphorylation to accomplish this process (Neira et al. 2002). Also, G strain metacyclics appear to mobilize intracellular calcium from acidocalcisomes whereas CL strain parasites preferentially use (1,4,5-inositol-triphosphate, $\mathrm{IP}_{3}$ dependent) endoplasmic reticulum stores during invasion (Neira et al. 2002). Preliminary results from comparative studies between metacyclic trypomastigotes and extracellular amastigotes of the 
G strain, indicated that drugs that interfere with ER calcium mobilization (thapsigargin, A23187 ionophore) do not affect invasion of treated amastigotes (Stecconi-Silva et al. 2003). Further analysis with other $\mathrm{IP}_{3}$-interfering compounds (caffeine, neomycin and U73122) confirmed that calcium mobilization in the parasite through $\mathrm{IP}_{3}$ mobilization is not relevant for cellular invasion by extracellular amastigotes of either G or CL strains (Table I, Fernandes A.B., unpublished observations). Interestingly, drugs that interfere with calcium mobilization from acidocalcisomes (ionomycin, nigericin, $\mathrm{NH}_{4} \mathrm{Cl}$ ) inhibit cell invasion by parasites of both strains (Fernandes A.B., unpublished observations), in contrast to the results of metacyclic trypomastigotes (Neira et al. 2002). From the host cell point of view, contact with TCT (Tardieux et al. 1994) or metacyclic trypomastigotes (Dorta et al. 1995), but not epimastigotes (Tardieux et al. 1994) give rise to transient calcium influxes. We have observed that cell extracts of extracellular amastigotes of both $\mathrm{G}$ and $\mathrm{CL}$ strains also induce calcium influxes in HeLa cells loaded with Fura-2 (Fernandes A.B., unpublished observations). These observations suggest that the distinct signaling pathways detected in metacyclics are not retained by extracellular amastigotes from the two phylogenetic lineages (Table I). A comprehensive study of these signaling routes is currently being carried out in our laboratory.

\section{CELL INVASION AND INTRACELLULAR FATE OF INFECTIVE FORMS}

As mentioned earlier, an increasing number of both cellular and parasitic components that may be relevant for T. cruzi cell invasion have been identified over the last decades. A pragmatic analysis over the extensive and varied types of studies could lead the outsider to conclude that it is still not known precisely how $T$. cruzi invades host cells. For invasion to occur the parasite first has to attach, a process that can be separated from invasion by lowering temperature or fixing target cells (Andrews and Colli 1982, Meirelles et al. 1982a, Schenkman et al. 1991b). Several lines of evidence indicate, how- ever, that motile trypomastigotes (both TCTs and metacyclics) promptly attach to fixed cells and invade live cells through an active (meaning parasitedependent) mechanism that does not require intact host cell microfilaments (Schenkman et al. 1991b, Schenkman and Mortara 1992) but depends on parasite energy (Schenkman et al. 1991b). By contrast, extracellular amastigote attachment to fixed cells does not occur (Barros 1996) and invasion depends on functional host cell microfilaments (Mortara 1991, Procópio et al. 1998). A brief glance into these data immediately uncovers the complexity of the task.

Among the paradigmatic studies that laid new insights into the invasion mechanism is the description by the group of Norma Andrews that calciumdependent lysosomal recruitment takes place during trypomastigote invasion (Tardieux et al. 1992, 1994). According to this model, TCTs engage signaling processes that culminate with the formation of parasitophorous vacuole (Burleigh and Andrews 1998, Burleigh and Woolsey 2002).

New evidences on the participation of components of the early endocytic traffic such as dynamin and Rab5 have indicated that the lysosomal process might be more elaborate and downstream of earlier events (Wilkowsky et al. 2002). We have also recently obtained evidence that about $20 \%$ of CL strain (T. cruzi II) metacyclic trypomastigotes may also recruit the early endosome antigen EEA-1 when invading Vero cells harboring the bacterium Coxiella burnetii (Andreoli and Mortara 2003a).

Using a more quantitative approach to identify the role of phosphatidyl-inositol 3-kinase (PI3-K) on the lysosomal pathway, Woolsey et al. (2003) were able to firmly confirm previous observations by Wilkowsky et al. (2001) that this cellular key component could be involved in a lysosomeindependent $T$. cruzi internalization pathway by TCTs. Trypomastigotes that use this route mobilize phosphorylated inositides during the formation of the parasitophorous vacuole that then matures to become enriched in lysosomal marker LAMP-1. One important input of this work was that for the first 
time the relative contributions of each mode of entry, namely PI3-K (50\%), lysosome (20\%), and endosomal route $(20 \%)$ were estimated (Woolsey et al. 2003).

The available information on the mechanisms of amastigote penetration is comparatively scarcer than for trypomastigote. In studies on the interaction with macrophages, it has been described that members of the transialidase-like surface antigens engage mannose receptors to enter the professional phagocytes (Kahn et al. 1995). In non- phagocytic cells we so far have been able to identify the previously mentioned carbohydrate epitope (defined by Mab 1D9) as one of the potential molecular candidates on extracellular amastigote surface that interact with cultured mammalian cells. The relative role of PI3-K, endosomal and the already described LAMP-1 (Procópio et al. 1998) pathways in extracellular amastigote invasion will be examined with the appropriate GFP constructs, described by Woolsey et al. (2003) that recently became available to us.

Once inside host cells, trypomastigotes are thought to secrete TcTOX, a complement 9 (C9) factor-related molecule that at low $\mathrm{pH}$ will destroy the PV membrane and lead the parasite to the cytosol (Andrews et al. 1990). This lytic activity is likely to be facilitated by the parasite transialidase activity on lumenal glycoproteins that protect the parasitophorous vacuole (Hall et al. 1992). Infective extracellular amastigotes also secrete TcTOX (Y and $\mathrm{G}$ strains) and transialidase (Andrews and Whitlow 1989, Ley et al. 1990, Stecconi-Silva et al. 2003, L'Abbate and Fernandes unpublished observations). In recent studies we compared how $\mathrm{pH}$ affected cellular invasion and intracellular traffic of metacyclic trypomastigotes and extracellular amastigotes. We had previously confirmed that recently internalized amastigotes and metacyclic trypomastigotes ( $\mathrm{G}$ strain) can be found in LAMP-1containing PVs (Procópio et al. 1998). Raising intracellular $\mathrm{pH}$ with weak bases affected metacyclic invasion and escape from the PV, that was substantially delayed (from 2 to about 10h). By contrast, the kinetics of amastigote invasion and escape was not affected (Stecconi-Silva et al. 2003). In agreement with the idea that glycosylation of lysosomal lumenal glycoproteins is relevant for the protection of the PV membrane, both parasite forms promptly escape from PVs formed in $\mathrm{CHO}$ cells deficient in sialylation (Stecconi-Silva et al. 2003).

So far we have been able to identify TcTOX activities in isolated extracellular amastigotes (Stecconi-Silva et al. 2003) and tissue-culture derived trypomastigotes (Andreoli and Mortara 2003a). In contrast, metacyclic trypomastigotes display very weak transialidase activity and undetectable TcTOX (Andreoli and Mortara 2003a, Stecconi-Silva et al. 2003). Therefore, whereas extracellular amastigotes display a somewhat predictable behavior regarding cell invasion and escape, at present we do not have a consistent model to understand how metacyclic trypomastigotes actually escape from their PVs. Using polyclonal antibodies to $\mathrm{C} 9$, we have recently been able to detect by immunofluorescence what appears to be a TcTOXrelated component on intracellular amastigotes (Andreoli W.K., unpublished observations) and this tool may be useful to map this component throughout the intracellular traffic of the different infective forms. Another interesting observation regarding metacyclic trypomastigote traffic is that the acquisition of LAMP-1 molecules by the forming PV does not parallel its acidification, monitored in vivo by Lysotracker, a fluorescent probe for acidic intracellular compartments (Molecular Probes, OR, USA, Andreoli W.K., unpublished observations). This may indicate that the precise events that lead to PV maturation might be more elaborate than previously imagined.

\section{INVASION BY T. cruzi OF Vero CELLS COLONIZED WITH Coxiella burnetii}

The study of cell co-infection may allow the observation of the behavior of pathogens in the presence of one another, and provide new insights on the course of infection and interaction of each pathogen with the endocytic pathway (Rabinovitch 


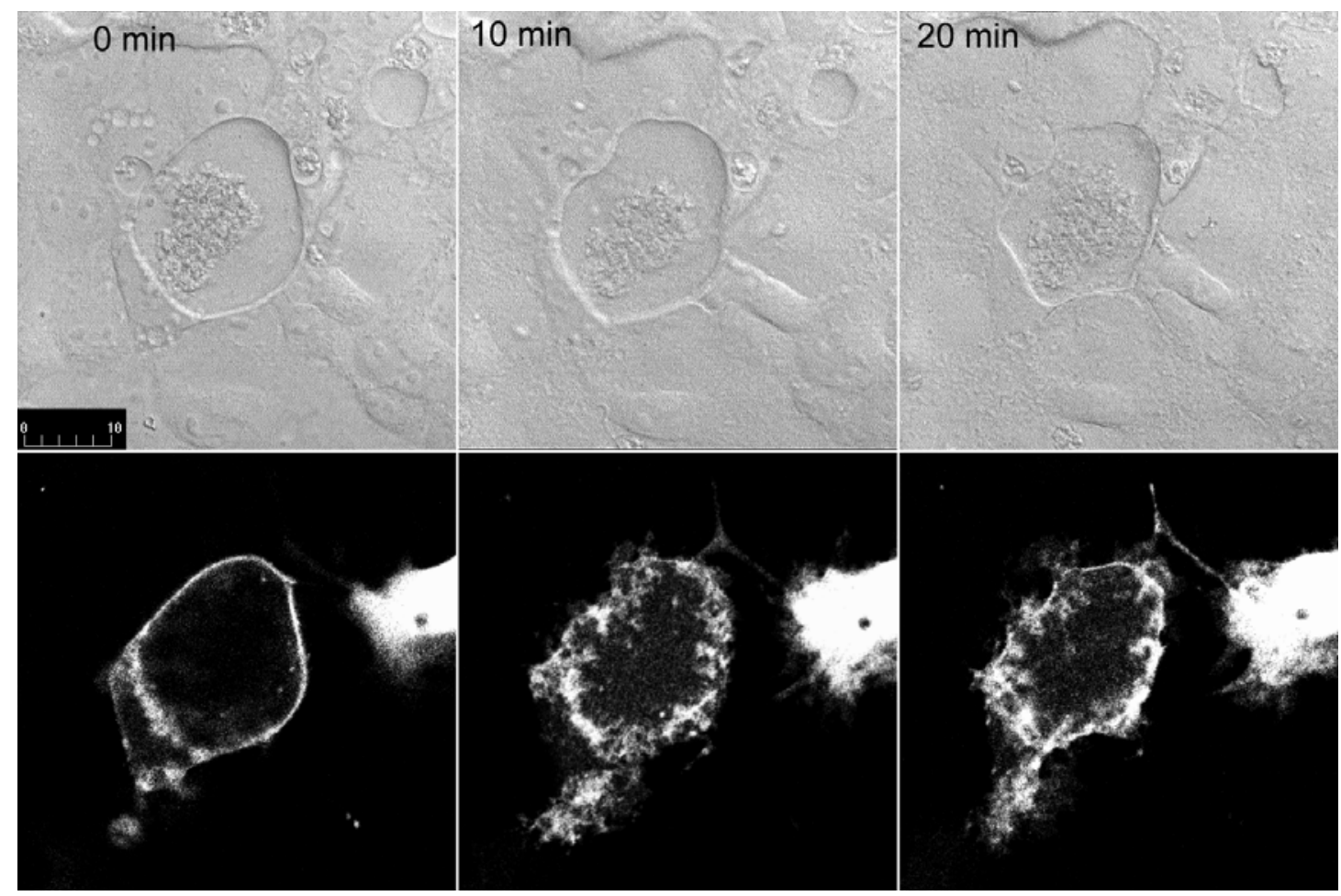

Fig. 5 - Bafilomycin A1 induces dispersion of EGFP-LAMP1-labeled C. burnetti vacuoles. Sequential series of DIC images with the corresponding fluorescence in cells treated with Baf 1A. Bar in $\mu \mathrm{m}$.

et al. 1999, Rabinovitch and Veras 1996). In the last years, we began to examine the behavior of $T$. cruzi trypomastigotes upon invasion of cells that had been previously colonized with Coxiella burnetii, an obligate intracellular bacterium and causative agent of $\mathrm{Q}$ fever, an opportunistic human pneumonia. C. burnetii may inhabit both phagocytic and non-phagocytic cells (Baca and Paretsky 1983) where it forms large cytoplasmic vacuoles with lysosomal characteristics by acquisition of hydrolases and lysosomal markers (LAMP-1 and LAMP-2). C. burnetii is a well adapted organism that accomplishes all metabolic processes at low pH (Hackstadt and Williams 1981), as it has been established that their vacuoles maintain an acidic $\mathrm{pH}$ during infection (Maurin et al. 1992). A previously demonstrated hallmark of $C$. burnetii vacuoles is their fusogenicity: from inert particles to different intracellular pathogens can easily be targeted to this new compartment (Rabinovitch et al. 1999). A very use- ful quality of this system is that persistent infection can be easily established and cells harboring large C. burnetti vacuoles can be maintained in culture for several weeks. We began to exploit this feature to examine the co-infection with T. cruzi.

\section{TRYPOMASTIGOTES}

The presence of the bacterium (in persistent infections) per se can hinder infection by trypomastigotes (TCTs and metacyclics, CL strain) in Vero cells. However, inhibitors of vacuolar ATPases and weak bases that also raise intravacuolar $\mathrm{pH}$ have a dramatic effect on the invasion processes (Andreoli and Mortara 2003a). Whereas in Vero cells, raising $\mathrm{pH}$ reduces infectivity, presumably by affecting the lysosomal pathway (Andrews 1995, Tardieux et al. 1992), cells colonized with $C$. burnetii are more susceptible to trypomastigote invasion than the untreated controls. This unexpected effect probably reflects the fragmentation of the large vacuole when 
cells are treated with these drugs (Figure 5). One possibility is that LAMP-1 molecules become increasingly exposed at the cell surface thus facilitating the lysosomal route for internalization (Kima et al. 2000).

The ultimate goal of these experiments was to transfer trypomastigotes from the cytoplasm to the $C$. burnetii vacuole, through the fusion between the bacterium vacuole and PV. Metacyclic trypomastigotes were readily transferred but TCTs escaped from their PVs and released themselves into the cytoplasm. This difference can be accounted for by the low TcTOX and transialidase activities in metacyclics: since these forms remain longer in their PVs (Stecconi-Silva et al. 2003), they have more opportunities to be transferred to the $C$. burnetii vacuole (Andreoli and Mortara 2003a). Intravacuolar $\mathrm{pH}$ measurements in live cells indicated that trypomastigotes are preferentially transferred to more acidic vacuoles ( $\mathrm{pH} 4.0-4.7)$, and raising vacuolar $\mathrm{pH}$ with the compounds mentioned above, dramatically decreased transfer efficiency (Andreoli and Mortara 2003a). A previously undescribed release of LAMP-1 from the PV is shown in figure 6. In these studies with cells transfected with GFPLAMP-1 we have also obtained evidence that internalization of metacyclic trypomastigotes may involve erratic translocations of parasites surrounded by PV membrane through the cytoplasm (Figure 6). Comparative studies between TCTs and metacyclic trypomastigotes of $T$. cruzi I and T. cruzi II strains suggested, again, that trafficking in Vero cells colonized with $C$. burnetii may vary substantially among the different isolates and infective forms (Table I, L'Abbate C., unpublished observations).

\section{AmASTIGOTES}

Bearing in mind our previous experience with amastigote invasion of HeLa and Vero cells, we have been examining how the intracellular bacteria persistently growing inside Vero cells could affect the process. We compared T. cruzi I (G strain) extracellular amastigotes with $T$. cruzi II parasites (CL strain). Unlike to what was seen for the trypo-

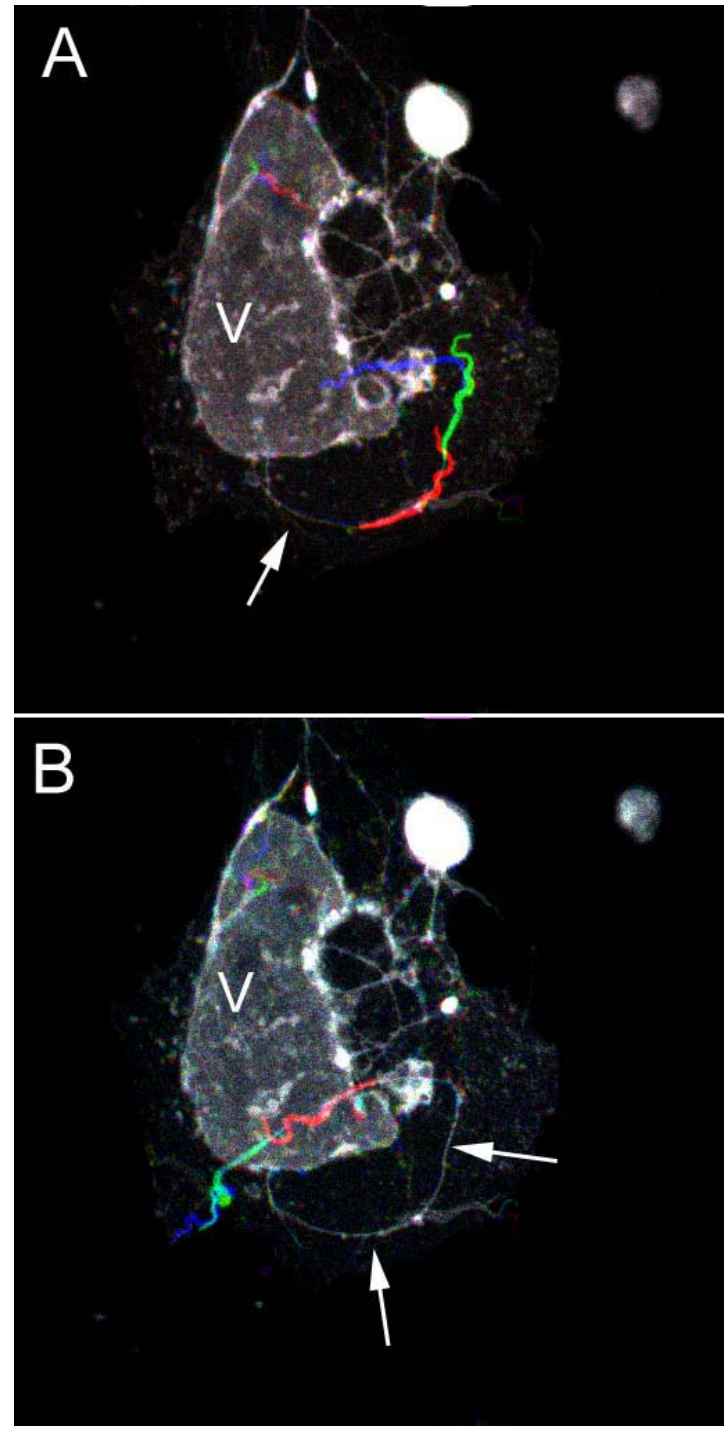

Fig. 6-T. cruzi metacyclic PVs move inside Vero cells harboring C. burnetti leaving trails of LAMP-1. Vero cells colonized with $C$. burnetii were transfected with eGFP-LAMP1 then infected with metacyclic trypomastigotes (CL strain). A, B: sequential RGB merged images (10 seconds interval between images), showing moving parasites (in colors) with the LAMP-1 trail (arrows) and large vacuole (V) labeled with eGFP-LAMP-1 that remain still (thus in gray tones) in the timeframe of the experiment.

mastigotes, the presence of the bacterium per se increased amastigote infectivity of parasites of both strains (Table I). The observation that the transference of amastigotes to the $C$. burnetii vacuole was 
enhanced by weak bases but reduced by vacuolar ATPase inhibitors (Fernandes M.C., unpublished observations) is a strong evidence that the intracellular trafficking compartments used by amastigotes (and possibly their maturation) are different form those used by trypomastigotes (Andreoli and Mortara 2003a).

\section{GROWTH AND DifFERENTIATION OF Trypomastigotes Within the \\ Coxiella burnetii VACUOLE}

Once inside the $C$. burnetii vacuole, metacyclics differentiate into amastigotes as well as in epimastigote-like forms. This can be demonstrated by morphological examination and immunolabeling parasites with specific anti-amastigote (Barros et al. 1997) and anti-epimastigote (Almeida-de-Faria et al. 1999) antibodies. Intravacuolar $\mathrm{pH}$ measurements in vivo indicate that in spite of the acidic milieu, amastigotes retained a neutral $\mathrm{pH}$ in their cytoplasm while growing in the bacterium vacuole (Andreoli and Mortara 2003b). Using T. cruzi transfected with histone 2-GFP (Yamauchi et al. 1997) we confirmed that amastigote division takes about 70 min (Figure 7). In spite of several attempts, we could not demonstrate the transformation of amastigotes growing inside the $C$. burnetii vacuole into trypomastigotes.

Indications that cytoplasmic parasites grew substantially outside the vacuole in doubly-infected cells after $48-72 \mathrm{~h}$, without parallel infection by new trypomastigotes, led us to investigate whether amastigotes and/or epimastigotes could be escaping from the bacterium vacuole. Studies involving live cell video imaging, confocal and electron microscopy strongly suggested that these forms can escape from the bacterium vacuole (Andreoli and Mortara 2003b). We also demonstrated that amastigotes express C9-related TcTOX inside the $C$. burnetii vacuole that might be important for disruption of the bacterium vacuolar membrane.

\section{PERSPECTIVES}

It is clear that the mechanisms of invasion used by T. cruzi extracellular amastigotes, TCTs and metacyclic trypomastigotes are divergent. Added to this complexity is the finding of variation between isolates of the two main phylogenetic groups. The molecular information available for trypomastigote penetration, with the identification of putative ligands and their receptors, has not been paralleled in amastigote studies. So far, only a few parasite components, most of carbohydrate nature have been identified as important components for cell invasion. Emerging evidence suggest that these infective forms might, presumably by engaging different receptors, be trafficking in cytoplasmic compartments of distinct composition and maturation characteristics. The introduction of the companion pathogen, C. burnetii, has revealed new insights into these intricate processes. Mapping amastigote ligands and their putative receptors should provide molecular tools to explore these interactions in deeper detail. Also, the availability of GFP-tagged components acting in host cell endocytic and lysosomal pathways will offer the unique opportunity to carry out live cell experiments.

\section{ACKNOWLEDGMENTS}

We are grateful to our colleagues Nobuko Yoshida and José Franco da Silveira for their comments and suggestions on the manuscript. We are also indebted to our colleague and friend Michel Rabinovitch for introducing us to the Coxiella world and relentless critic spirit. The financial support from the Brazilian agencies Conselho Nacional de Desenvolvimento Científico e Tecnológico (CNPq), Fundação de Amparo à Pesquisa do Estado de São Paulo (FAPESP), and Coordenação de Aperfeiçoamento de Pessoal de Nível Superior (CAPES) through fellowships and research grants is also fully acknowledged.

\section{RESUMO}

O agente etiológico da doença de Chagas, Trypanosoma cruzi, ocorre como cepas ou isolados que podem ser agru- 


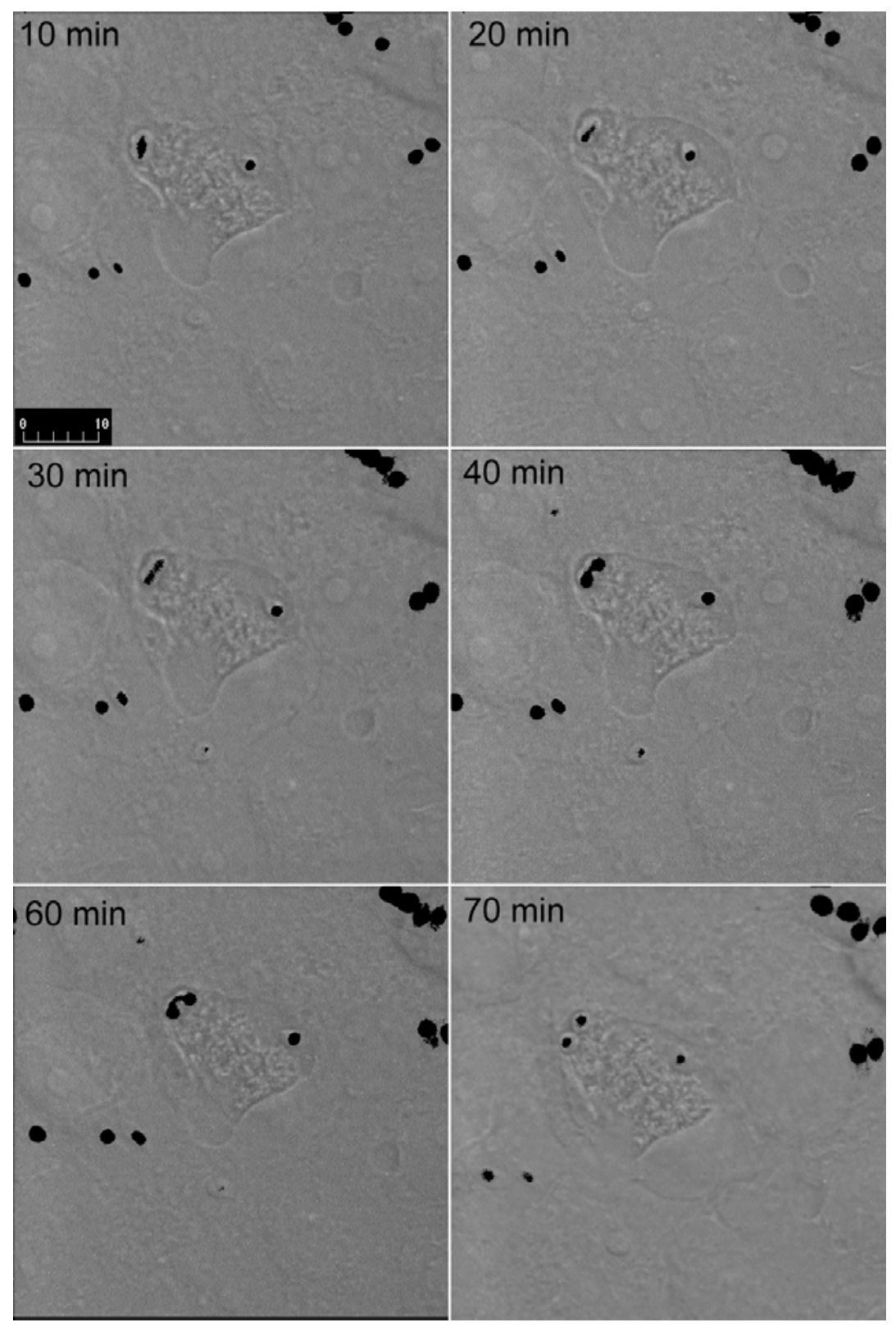

Fig. 7 - T. cruzi amastigotes divide within C. burnetti vacuole. Metacyclic trypomastigotes invade Vero cells colonized with $C$. burnetti and after $48 \mathrm{~h}$ the resulting amastigotes (here labeled with Histone H2-GFP, in black, over grey DIC background images) are seen dividing. Bar in $\mu \mathrm{m}$.

pados em duas grandes linhagens filogenéticas: T. cruzi I associada ao ciclo silvestre e T. cruzi II ligada à doença humana. No hospedeiro mamífero o parasita tem que invadir células, e vários estudos relacionam as formas flageladas tripomastigotas neste processo. Diferentes compo- nentes de superfície dos parasitas e alguns dos respectivos receptores foram identificados. Em nosso trabalho temos procurado compreender como amastigotas, que normalmente são encontrados crescendo no citoplasma, podem invadir células de mamíferos com infectividade compa- 
rável às dos tripomastigotas. Encontramos diferenças nas respostas celulares induzidas por amastigotas e tripomastigotas em relação a componentes de citoesqueleto e projeções de membrana ricas em actina. Amastigotas de cepas de T. cruzi I gerados extracelularmente, podem apresentar infectividade maior que tripomastigotas metacíclicos para linhagens celulares e células com expressão alterada em diferentes classes de componentes celulares. Células albergando a bactéria Coxiella burnetii tem nos permitido obter novos enfoques sobre as propriedades de tráfego intracelular das diferentes formas infectivas do $T$. cruzi, revelando requerimentos inesperados para o parasita transitar entre seu vacúolo parasitóforo até seu destino final no citoplasma da célula hospedeira.

Palavras-chave: Trypanosoma cruzi, invasão celular, amastigotas, tripomastigotas, escape do vacúolo parasitóforo, tráfego, Coxiella burnetii, linhagens filogenéticas.

\section{REFERENCES}

Almeida-de-Faria M, Freymuller E, Colli W and Alves MJ. 1999. Trypanosoma cruzi: characterization of an intracellular epimastigote-like form. Exp Parasitol 92: 263-274.

Alves MJM, Abuin G, Kuwajima VY and Colli W. 1986. Partial inhibition of trypomastigote entry into cultured mammalian cells by monoclonal antibodies against a surface glycoprotein of Trypanosoma cruzi. Mol Biochem Parasitol 21: 75-82.

ANDREOli WK and Mortara RA. 2003a. Acidification modulates the traffic of Trypanosoma cruzi trypomastigotes in Vero cells harboring Coxiella burnetti vacuoles. Int J Parasitol 33: 185-197.

Andreoli WK And Mortara RA. 2003b. Traffic of Trypanosoma cruzi trypomastigotes within Vero cells colonized with Coxiella burnetiiI: invasion, transference and... escape? Rev Inst Med Trop São Paulo 45: 36.

ANDREws NW. 1989. Presence of antibodies to the major surface glycoprotein of Trypanosoma cruzi amastigotes in sera from chagasic patients. Am J Trop Med Hyg 40: 46-49.

ANDREws NW. 1995. Lysosome recruitment during host cell invasion by Trypanosoma cruzi. Trends Cell Biol 5: 133-137.

ANDRews NW ANd Colli W. 1982. Adhesion and interiorization of Trypanosoma cruzi in mammalian cells. J Protozool 29: 264-269.
Andrews NW ANd Whitlow MB. 1989. Secretion by Trypanosoma cruzi of a hemolysin active at low $\mathrm{pH}$. Mol Biochem Parasitol 33: 249-256.

Andrews NW, Hong K-S, Robbins ES And NussenZWEIG V. 1987. Stage-specific surface antigens expressed during the morphogenesis of vertebrate forms of Trypanosoma cruzi. Exp Parasitol 64: 474-484.

Andrews NW, Abrams CK, Slatin SL and Griffiths G. 1990. A T. cruzi-secreted protein immunologically related to the complement component $\mathrm{C} 9$ : evidence for membrane pore-forming activity at low $\mathrm{pH}$. Cell 61: 1277-1287.

Baca OG and Paretsky D. 1983. Q fever and Coxiella burnetii: a model for host-parasite interactions. Microbiol Rev 47: 127-149.

Barbosa HS and Meirelles MNL. 1995. Evidence of participation of cytoskeleton of heart muscle cells during the invasion of Trypanosoma cruzi. Cell Struct Funct 20: 275-284.

BARros HC. 1996. Estudos in vitro sobre a interação de formas amastigotas do Trypanosoma cruzi com células de mamíferos. p. 1-176. PhD Thesis, Escola Paulista de Medicina, São Paulo, Brasil.

Barros HC, Silva S and Mortara RA. 1993. Monoclonal antibodies that inhibit invasion of cultured cells, detected during studies of Trypanosoma cruzi amastigote-host cell interactions. Mem Inst Oswaldo Cruz (Rio de Janeiro) 88 (Suppl 1): 105.

Barros HC, Silva S, Verbisck NV, Araguth MF, Tedesco RC, Procópio DO and Mortara RA. 1996. Release of membrane-bound trails by Trypanosoma cruzi amastigotes onto modified surfaces and mammalian cells. J Eukaryot Microbiol 43: 275-285.

Barros HC, Verbisck NV, Silva S, Araguth MF and Mortara RA. 1997. Distribution of epitopes of Trypanosoma cruzi amastigotes during the intracellular life cycle within mammalian cells. J Eukaryot Microbiol 44: 332-344.

Behbehani K. 1973. Developmental cycles of Trypanosoma (Schyzotrypanum) cruzi (Chagas, 1909) in mouse peritoneal macrophages in vitro. Parasitology 66: 343-353.

Bourdet-Sicard R, Egile C, Sansonetti PJ and Tran VN. 2000. Diversion of cytoskeletal processes by Shigella during invasion of epithelial cells. Microbes Infect 2: 813-819. 
Burleigh BA AND ANDrews NW. 1998. Signaling and host cell invasion byTrypanosoma cruzi. Curr Opin Microbiol 1: 461-465.

Burleigh BA And Woolsey AM. 2002. Cell signalling and Trypanosoma cruzi invasion. Cell Microbiol 4: 701-711.

Carvalho RMG, Meirelles MNL, De Souza W and LEON W. 1981. Isolation of the intracellular stage of Trypanosoma cruzi and its interaction with mouse macrophages in vitro. Infect Immun 33: 546-554.

Clerc P and Sansonetti PJ. 1987. Entry of Shigella flexneri into HeLa cells: Evidence for directed phagocytosis involving actin polymerization and myosin accumulation. Infect Immun 55: 2681-2688.

Cossart P. 1997. Subversion of the mammalian cell cytoskeleton by invasive bacteria. J Clin Invest 99: 2307-2311.

Cunningham CC, Stossel TP and Kwiatkowski DJ. 1991. Enhanced motility in NIH 3T3 fibroblasts that overexpress gelsolin. Science 251: 1233-1236.

Cunningham CC, Gorlin JB, Kwiatkowski DJ, Hartwig JH, JANMEy PA, Byers HR AND STOSSEL TP. 1992. Actin-binding protein requirement for cortical stability and efficient locomotion. Science 255 : 325-327.

Deutscher SL, Nuwayhid N, Stanley P, Briles EI AND Hirschberg CB. 1984. Translocation across Golgi vesicle membranes: a CHO glycosylation mutant deficient in CMP-sialic acid transport. Cell 39: 295-299.

Dorta ML, Ferreira AT, Oshiro MEM and Yoshida N. 1995. $\mathrm{Ca}^{2+}$ signal induced by Trypanosoma cruzi metacyclic trypomastigote surface molecules implicated in mammalian cell invasion. Mol Biochem Parasitol 73: 285-289.

DRAMSI S AND CoSSART P. 1998. Intracellular pathogens and the actin cytoskeleton. Annu Rev Cell Dev Biol 14: 137-166.

Dvorak JA AND Hyde TP. 1973. Trypanosoma cruzi: Interaction with vertebrate cells in vitro. Individual interactions at the cellular and subcellular levels. Exp Parasitol 34: 268-283.

Fernandes AB And Mortara RA. 2004. Invasion of MDCK epithelial cells with altered expression of Rho GTPases by Trypanosoma cruzi amastigotes and metacyclic trypomastigotes of strains from the two major phylogenetic lineages. Microbes Infect 6: 460-467.

FrischKNECHT F AND WAY M. 2001. Surfing pathogens and the lessons learned for actin polymerization. Trends Cell Biol 11: 30-38.

Goosney DL, Gruenheid S And Finlay BB. 2000. Gut feelings: enteropathogenic E. coli (EPEC) interactions with the host. Annu Rev Cell Dev Biol 16: 173-189.

Hackstadt T and Williams JC. 1981. Biochemical stratagem for obligate parasitism of eukaryotic cells by Coxiella burnetii. Proc Natl Acad Sci USA 78: 3240-3244.

HaLl A. 1994. Small GTP-binding proteins and the regulation of the actin cytoskeleton. Annu Rev Cell Biol 10: 31-54.

Hall BF, Webster P, Ma AK, Joiner KA And Andrews NW. 1992. Desialylation of lysosomal membrane glycoproteins by Trypanosoma cruzi: A role for the surface neuraminidase in facilitating parasite entry into the host cell cytoplasm. J Exp Med 176: 313-325

Hudson L, Snary D and Morgan SJ. 1984. Trypanosoma cruzi: continuous cultivation with murine cell lines. Parasitology 88: 283-294.

IidA K, Whitlow MB and Nussenzweig V. 1989. Amastigotes of Trypanosoma cruzi escape destruction by the terminal complement components. J Exp Med 169: 881-891.

Jou TS AND NeLson WJ. 1998. Effects of regulated expression of mutant RhoA and Rac1 small GTPases on the development of epithelial (MDCK) cell polarity. J Cell Biol 142: 85-100.

Kahn S, Wleklinski M, Aruffo A, Farr A, Coder D AND KAHN M. 1995. Trypanosoma cruzi amastigote adhesion to macrophages is facilitated by the mannose receptor. J Exp Med 182: 1243-1258.

Kima PE, Burleigh BA And Andrews NW. 2000. Surface-targeted lysosomal membrane glycoprotein1 (Lamp-1) enhances lysosome exocytosis and cell invasion by Trypanosoma cruzi. Cell Microbiol 2: 477-486.

Kozma R, Ahmed S, Best A and Lim L. 1995. The Ras-related protein $\mathrm{Cdc} 42 \mathrm{Hs}$ and bradykinin promote formation of peripheral actin microspikes and filopodia in Swiss 3 T3 fibroblasts. Mol Cell Biol 15: 1942-1952. 
Kress Y, Bloom BR, Wittner M, Rowen A and TANoWITZ H. 1975. Resistance of Trypanosoma cruzi to killing by macrophages. Nature 257: 394-396.

Ley V, Andrews NW, Robbins ES ANd NusSEnZweIG V. 1988. Amastigotes of Trypanosoma cruzi sustain an infective cycle in mammalian cells. J Exp Med 168: 649-659.

Ley V, Robbins ES, Nussenzweig V And Andrews NW. 1990. The exit of Trypanosoma cruzi from the phagosome is inhibited by raising the $\mathrm{pH}$ of acidic compartments. J Exp Med 171: 401-413.

Maurin M, Benoliel AM, Bongrand P and Rault D. 1992. Phagolysosome of Coxiella burnetii - infected cell lines maintain an acidic $\mathrm{pH}$ during persistent infection. Infect Immun 60: 5013-5016.

Meirelles MNL, Araujo-Jorge TC and de Souza W. 1982a. Interaction of Trypanosoma cruzi with macrophages in vitro: dissociation of the attachment and internalization phases by low temperature and cytochalasin B. Z Parasitenkd 68: 7-14.

Meirelles MNL, Chiari E ANd de Souza W. 1982 b. Interaction of bloodstream, tissue-culture-derived and axenic culture-derived trypomastigotes of Trypanosoma cruzi with macrophages. Acta Trop 39: 195-203.

Meirelles MNL, Araujo-Jorge TC, Miranda CF, de Souza W AND BARbosa HS. 1986. Interaction of Trypanosoma cruzi with heart muscle cells: ultrastructural and cytochemical analysis of endocytic vacuole formation and effect upon myogenesis in vitro. Eur J Cell Biol 41: 198-206.

Meirelles MNL, Araujo-Jorge TC, de Souza W, MoreIRA AL ANd BARbosa HS. 1987. Trypanosoma cruzi: phagolysosomal fusion after invasion into non professional phagocytic cells. Cell Struct Funct 12: 387-393.

Meirelles Mnl, Juliano L, Carmona E, Silva SG, Costa EM, Murta ACM and Scharfstein J. 1992. Inhibitors of the major cysteinyl proteinase (GP57/51) impair host cell invasion and arrest the intracellular development of Trypanosoma cruzi in vitro. Mol Biochem Parasitol 52: 175-184.

Melo RC and Brener Z. 1978. Tissue tropism of different Trypanosoma cruzi strains. J Parasitol 64: 475482.

Meyer H and Xavier de Oliveira M. 1948. Cultivation of Trypanosoma cruzi in tissue cultures: a four- year study. Parasitology 39: 91-94.

Milder RV and Kloetzel JK. 1980. The development of Trypanosoma cruzi in macrophages in vitro. Interaction with lysosomes and host cell fate. Parasitology 80: $139-145$.

Ming M, Ewen ME and Pereira MEA. 1995. Trypanosome invasion of mammalian cells requires activation of the TGF $\beta$ signaling pathway. Cell 82: 287-296.

MortaRA RA. 1991. Trypanosoma cruzi: amastigotes and trypomastigotes interact with different structures on the surface of HeLa cells. Exp Parasitol 73: 1-14.

Mortara RA, Procópio DO, Barros HC, Verbisck NV, Andreoli WK, Silva RB and Silva S. 1999. Features of host cell invasion by different infective forms of Trypanosoma cruzi. Mem Inst Oswaldo Cruz 94 (Suppl 1): 135-137.

Neira I, Ferreira AT and Yoshida N. 2002. Activation of distinct signal transduction pathways in Trypanosoma cruzi isolates with differential capacity to invade host cells. Int J Parasitol 32: 405-414.

Nobes CD And Hall A. 1995. Rho, Rac, and Cdc42 GTPases regulate the assembly of multimolecular focal complexes associated with actin stress fibers, lamellipodia, and filopodia. Cell 81: 53-62.

Nogueira N And Cohn Z. 1976. Trypanosoma cruzi: mechanism of entry and intracellular fate in mammalian cells. J Exp Med 143: 1402-1420.

Ortega-Barria E and Pereira MEA. 1991. A novel Trypanosoma cruzi heparin-binding protein promotes fibroblast adhesion and penetration of engineered bacteria and trypanosomes into mammalian cells. Cell 67: 411-421.

Pan AA and McMahon-Pratt D. 1989. Amastigote and epimastigote stage-specific components of Trypanosoma cruzi characterized by using monoclonal antibodies. J Immunol 143: 1001-1008.

Procópio DO, Silva S, Cunningham CC and Mortara RA. 1998. Trypanosoma cruzi: effect of protein kinase inhibitors and cytoskeletal protein organization and expression on host cell invasion by amastigotes and metacyclic trypomastigotes. Exp Parasitol 90: $1-13$.

Procópio DO, Barros HC and Mortara RA. 1999. Actin-rich structures formed during the invasion of 
cultured cells by infective forms of Trypanosoma cruzi. Eur J Cell Biol 78: 911-924.

Rabinovitch M and Veras PS. 1996. Cohabitation of Leishmania amazonensis and Coxiella burnetii. Trends Microbiol 4: 158-161.

Rabinovitch M, Freymuller E, de Paula RA, Manque PM, Andreoli WK and Mortara RA. 1999. Cell co-infections with non-viral pathogens and the construction of doubly infected phagosomes. In: Phagocytosis: microbial invasion. Gordon S., editor. Series: Advances in Cell and Molecular Biology of Membranes and Organelles, volume 6, JAI Press Inc. Stamford, Connecticut, p. 349-371.

Ridley AJ and Hall A. 1992. The small GTP-binding protein rho regulates the assembly of focal adhesions and actin stress fibers in response to growth factors. Cell 70: 389-399.

Ridley AJ, Paterson HF, Johnston CL, Diekmann D AND Hall A. 1992. The small GTP-binding protein rac regulates growth factor-induced membrane ruffling. Cell 70: 401-410.

Rosenshine I AND FInLAY BB. 1993. Exploitation of host signal transduction pathways and cytoskeletal functions by invasive bacteria. BioEssays 15: 17-24.

Scharfastein J And Morrot A. 1999. A role for extracellular amastigotes in the immunopathology of Chagas disease. Mem Inst Oswaldo Cruz (Rio de Janeiro) 94: 51-63.

Schenkman S And Mortara RA. 1992. HeLa cells extend and internalize pseudopodia during active invasion by Trypanosoma cruzi trypomastigotes. J Cell Sci 101: 895-905.

Schenkman S, Andrews NW, Nussenzweig V and RobBINs ES. 1988. Trypanosoma cruzi invade a mammalian epithelial cell in a polarized manner. Cell 55: $157-165$.

Schenkman S, Diaz C and Nussenzweig V. 1991a. Attachment of Trypanosoma cruzi trypomastigotes to receptors at restricted cell surface domains. Exp Parasitol 72: 76-86.

Schenkman S, Robbins ES and Nussenzweig V. 1991b. Attachment of Trypanosoma cruzi to mammalian cells requires parasite energy, and invasion can be independent of the target cell cytoskeleton. Infect Immun 59: 645-654.

Silva EO, Saraiva EMB, de Souza W and Souto-
PADRón T. 1998. Cell surface characterization of amastigotes of Trypanosoma cruzi obtained from different sources. Parasitol Res 84: 257-263.

Silva MLM, Mortara RA, Barros HC, de Souza W AND TRABUlsi LR. 1989. Aggregation of membraneassociated actin filaments following localized adherence of enteropathogenic Escherichia coli to HeLa cells. J Cell Sci 93: 439-446.

Souto RP, Fernandes O, Macedo AM, Campbell DA AND Zingales B. 1996. DNA markers define two major phylogenetic lineages of Trypanosoma cruzi. Mol Biochem Parasitol 83: 141-152.

Stecconi-Silva RB, Andreoli WK and Mortara RA. 2003. Parameters affecting cellular invasion and escape from the parasitophorous vacuole by different infective forms of Trypanosoma cruzi. Mem Inst Oswaldo Cruz 98: 953-958.

Tanowitz H, Wittner M, Kress Y and Bloom B. 1975. Studies of in vitro infection by Trypanosoma cruzi. I Ultrastructural studies on the invasion of macrophages and L-cells. Am J Trop Med Hyg 24: 25-33.

Tardieux I, Webster P, Ravesloot J, Boron W, LunN JA, Heuser JE AND ANDrews NW. 1992. Lysosome recruitment and fusion are early events required for trypanosome invasion of mammalian cells. Cell 71: 1117-1130.

Tardieux I, NATHanson MH and ANDrews NW. 1994. Role in host cell invasion of Trypanosoma cruziinduced cytosolic-free $\mathrm{Ca}^{2+}$ transients. J Exp Med 179: 1017-1022.

Tran VN, Bourdet-Sicard R, Dumenil G, Blocker A AND SANSONETTI PJ. 2000. Bacterial signals and cell responses during Shigella entry into epithelial cells. Cell Microbiol 2: 187-193.

Ulisses de Carvalho TM and de Souza W. 1986. Infectivity of amastigotes of Trypanosoma cruzi. Rev Inst Med Trop São Paulo 28: 205-212.

Umezawa ES, Milder RV and Abrahamsohn IA. 1985. Trypanosoma cruzi amastigotes: development in vitro and infectivity in vivo of the forms isolated from spleen and liver. Acta Trop 42: 25-32.

Verbisck NV, Silva S And Mortara RA. 1998. Trypanosoma cruzi: amastigote polymorphism defined by monoclonal antibodies. Braz J Med Biol Res 31: 1583-1591. 
Villalta F and Kierszenbaum F. 1982. Growth of isolated amastigotes of Trypanosoma cruzi in cellfree medium. J Protozool 29: 570-576.

Wilkowsky SE, Barbieri MA, Stahl P and Isola ELD. 2001. Trypanosoma cruzi: phosphatidylinositol 3-Kinase and protein kinase B activation is associated with parasite invasion. Exp Cell Res 264: 211-218.

Wilkowsky SE, BARbieri MA, STAHL PD AND Isola EL. 2002. Regulation of Trypanosoma cruzi invasion of nonphagocytic cells by the endocytically active GTPases dynamin, Rab5, and Rab7. Biochem Biophys Res Commun 291: 516-521.
Woolsey AM, Sunwoo L, Petersen CA, Brachmann SM, Cantley LC and Burleigh BA. 2003. Novel PI 3-kinase-dependent mechanisms of trypanosome invasion and vacuole maturation. J Cell Sci 116: 3611-3622.

Yamauchi LM, Ullu E and Schenkman S. 1997. Expression of green fluorescent protein in Trypanosoma cruzi. Mem Inst Oswaldo Cruz (Rio de Janeiro) 92: 163.

Yoshida N. 2002. Trypanosoma cruzi cell invasion mechanisms. World Class Parasites Volume IV: American Trypanosomiasis, Ed. Tyler KM, Miles MA. Kluwer Academic Publishers. 